STEM Educational Lab • STEM Educational Lab journal 1(1)/2020

\title{
Aspecte de management privind domeniul aeronavelor fără pilot
}

\section{Cristina Negulescu}

Published on: Aug 12, 2020

DOI: $10.21428 / 52 b a 1 f f e . d 64 d 1 b 4 f$

License: Creative Commons Attribution 4.0 International License(CC-BY 4.0). 


\section{ASPECTE DE MANAGEMENT PRIVIND DOMENIUL AERONAVELOR FĂRĂ PILOT}

\section{Cristina NEGULESCU}

Academia Forțelor Aeriene “HENRI COANDĂ”, Brașov, Romania

negulescucristina@ymail.com

Rezumat: Tehnologia sistemelor aeriene fără pilot s-a evidențiat prin adaptabilitatea vectorilor în ultimele decenii la diferite misiuni militare și civile, cu toate acestea limitele care apar în orice domeniu duc adesea la compromisuri. Proiectarea și construcția în domeniul sistemelelor aeriene se concentrează pe concepte inovatoare aeromecanice care duc la un consum enrgetic redus în misiuni și o viteza mare de reactie. Cerinţele aerodinamice ale UAV depind direct de caracteristicile tehnice, calitătile de zbor, condiții de operare și efectele care apar pe timpul misiunilor.

Articolul conține o serie de repere relevante privind standardizarea și reglementările naționale și internaționale în domeniul UAV.

Cuvinte cheie: $U A V$, standarde, NATO, DoD, management inteligent

\section{Acronime}

\begin{tabular}{|l|l|}
\hline DoD & Deparment of Defence \\
\hline DSPO & Defense Standardization Program Office \\
\hline JAUS & Joint Architecture for Unmanned Systems \\
\hline JCGUAV & $\begin{array}{l}\text { Joint Capability Group on Unmanned Aerial } \\
\text { Vehicles }\end{array}$ \\
\hline JIPT & Joint Integrated Product Team \\
\hline NAVAIR & Naval Air Systems Command \\
\hline NGS & Non-Guvernamental Standard \\
\hline
\end{tabular}




\begin{tabular}{|l|l|}
\hline OMB & Office of Management and Budget \\
\hline$P G$ & NATO's Planning Group \\
\hline$P L$ & Public Law \\
\hline$S D O$ & Standards Development Organization \\
\hline UAV/S & Unmaned Aerial Vehicles/Systems \\
\hline
\end{tabular}

\section{SCURT ISTORIC ȘI EVOLUȚIA UAV-URILOR}

Tehnologia sistemelor aeriene fără pilot s-a evidențiat prin adaptabilitatea vectorilor în deceniul trecut la diferite misiuni militare și civile, cu toate acestea limitele care apar în orice domeniu duc adesea la compromisuri. Limitele cele mai provocatoare sunt: masa, viteza, vulnerabilitatea la condițiile meteorologice, amenințări cu arme cinetice și non-cinetice, limite tehnologice (standarde de fiabilitate), limite legislative şi nu în ultimul rând limitele de gestionare a spațiului aerian. Proiectarea și construcția oricărui UAV trebuie să urmeze o serie de elemente: conceptul aerodinamic, viteza și autonomia, senzorii ambarcați, integrarea datelor, managementul termic și amprenta acustică / radar. Soluțiile inovatoare pot marca toate etapele în realizarea unui produs aerian fără pilot atât din punct de vedere conceptual și de proiectare, cât şi prototipare și fabricație (materiale inteligente neconventionale, energie, propulsie) sau exploatare (autonomie).

Proiectarea și construcția în sistemele aeriene se concentrează pe concepte inovatoare aeromecanice care duc la un consum redus de energie în misiuni și o viteza mare de reacție. Cerinţele aerodinamicii depind direct de caracteristicile tehnice, calitățile de zbor condiții de operare și efectele care apar pe timpul misiunilor. Aeronavele sunt proiectate, fabricate și testate în conformitate cu condițiile specifice și sunt utilizate în domenii de interes cu un factor de încărcare şi operare admisibil fără orice deformare permanentă care poate apărea dacă greutatea / sarcina specificată este depășită. Aerodinamic vorbind, geometria ar trebui să ofere maximum de performanță cu un consum energetic minim. [1]

Sistemul (UAS), poate reflecta la faptul că aceste entități tehnice complexe includ, pe lângă vehiculul în sine a stației de control de la sol, şi alte elemente auxiliare de 
sprijin, totodată mai este utilizat termenul de aeronave fără pilot (UA) atunci când se face referire directă la componenta aer a UAS.

\section{REPERE INTERNATIONALE PRIVIND STANDARDELE UAV}

În USA standardele (ca acorduri formale pentru proiectarea, fabricarea, testarea și performanța tehnologiei) sunt un factor cheie pentru interoperabilitate. PL104-113 (public law) cere ca organizațiile federale să adopte standarde comerciale, acolo unde este practic necesar, în special în cazul standardelor militare, [2]]. Unde sunt standardele necesare nu există sau se dovedesc insuficiente, circulara A-11911 a OMB îndrumă angajații federali să lucreze în cadrul acesteia. SDOs (standards development organization) sunt organizații interne sau internaționale care planifică, dezvoltă, stabilește sau coordonează voluntar standarde de consens folosind proceduri convenite care definesc deschiderea, consensul, echilibrul, datorat procesului [6]. DoD 4120.24M12 necesită ca DoD (Department of Defense) să ia în considerare mai întâi utilizarea non-guvernamentală standard (NGS), sau susțin revizuirea sau dezvoltarea unui NGS pentru a satisface nevoile DoD, de preferință folosind documente federale ori de câte ori este posibil. Pe lângă interoperabilitate, folosind standardele, promovează asigurarea calității produselor, favorizează obiectivele de achiziție comercială DoD, păstrează resursele DoD, sprijină baza industrială a Statelor Unite, promovează tehnologia cu dublă utilizare și îmbunătățește DoD's în capacități de mobilizare. [7]

Recunoscând relația dintre interoperabilitate și standarde, secretarul apărării al NATO, a delegat responsabilitatea subsecretarului pentru achiziții, tehnologie și logistică, care a atribuit ca agent executiv în Biroul Programului de Standardizare a Apărării (DSPO) încurajând și coordonând rolul DoD în elaborarea și utilizarea standardelor. DSPO este DoD reprezentant al Comitetului Interacțiunii mandatat de congres pentru politica de standarde, care este prezidat de Institutul Național pentru Standarde și Tehnologie (NIST) şi care este format din reprezentanți din majoritatea agențiilor federale. Comunitatea sistemelor fără echipaj a DoD, reprezentată de Comandamentul Naval al Sistemelor Aeriene (NAVAIR) PMA-263, care a început să dezvolte standarde UAS pentru NATO pe la mijlocul anilor '90 ca participant la Grupul de planificare 35 al NATO Planning Group (PG-35). Începând cu 2002, o serie de SDO (standards development organizations) au început să creeze comitete în rândurile lor pentru a răspunde nevoilor comunității unmanned din întreaga lume atât pentru SUA cât și internațional, precum și forţe militare, civile, și utilizatori comerciali ai 
sistemelor fără pilot. DSPO revizuiește și coordonează standarde elaborate de aceste comitete SDO pentru adoptarea de către DoD. []]

Personalul DoD participă în mod activ la aceste SDO în următoarele roluri de dezvoltare a standardelor pentru sisteme fără pilot, astfel:

- asigurarea creării standardelor relevante pentru DoD,

- protejarea formulării în standarde care ar avea scopuri încrucișate cu nevoile DoD (de exemplu, compromiterea dreptului DoD de a auto-certifica navigabilitatea aeronavei) și

- împiedicarea duplicării eforturilor de creare a standardelor între SDO.

Acest ultim rol este important, deoarece practicile industriei individuale oferă adesea pornirea de la zero al standardelor la nivel de comunitate și face participarea experților din industrie, care este în mare parte voluntar şi crucial în crearea de standarde demne. Prin urmare, devine important să nu se pierdă sprijinul voluntar al industriei către aceste SDO. Prin consensul lor procesele ajută SDO-urile la protejarea preocupărilor proprii ale entităților comerciale cu privire la expertiza acestor participanți pentru a produce standarde pentru cei fără reprezentare în comunitate. Personalul DoD ar trebui să încurajeze și să completeze participarea, nu să înlocuiască industriile comerciale din SDO. Comunitatea fără personal DoD participă la elaborarea standardelor prin trei căi:

- Agenția de Standardizare NATO, prin activitatea Grupului său Comun de Capacități la Vehicule Aeriene fără Pilot (JCGUAV),

- OSD JGRE, prin arhitectura comună pentru sisteme fără pilot (JAUS) și Biroul de Program al Departamentului Militar UAS, prin eforturi comune de integrare a spatiului aerian UAS şi

- Echipa de produse integrate (JIPT), []]. JIPT-ul de integrare a spațiului aerian UAS a fost creat pentru a concentra și alinia resursele DoD la elaborarea în timp util a standardelor, proceselor, procedurilor, soluților tehnice și politici cu recomandări pentru a răspunde nevoilor de acces la spațiul aerian pe termen scurt, mediu și lung al DoD UAS în comunitatea utilizatorilor. JIPT va integra activități de lucru cu FAA, OSD civile și militare. 


\section{REPERE NATIONALE PRIVIND STANDARDELE UAV}

Exploatarea zborurilor pentru utilizarea vehiculelor ca aeronave fără pilot în spațiul naţional aerian este reglementat de o serie de legi și reglementări prin delimitarea ambelor categorii de concepte (aerodină şi balon). Acestea sunt reglementate prin documente de admisibilitate pentru: „Unmanned Aerial Vehicle” - „vehicul aerian fără pilot” (UAV) - un vehicul care îndeplinește condițiile specificate în RCAR-AZAC. Acest vehicul aerian, funcționează cu o masă mai mică de 150 kg, [8]].

Un regulament recent definește și menține utilizarea spațiului aerian pentru UAV în conformitate cu tehnologiile moderne atât pentru evoluția anilor 2013 - 2019, şi nu numai, în special pentru vectorul aerian fără pilot sisteme de înregistrare și transmitere de date. Documentul definește termenii folosiți în domeniul UAV-ul și condițiile de operare în spațiul aerian național. Revizuirea aeronavelor fără pilot clasificându-le după prevederile legilor și reglementărilor în vigoare, ne trimite într-un domeniu relativ nou privind aeronautica. Diferența de echipament, implementat să conducă implicit la o dezvoltare având costuri minime, face diferența între capacitatea acestor aeronave care au deja propria lor istorie și dezvoltarea împreună cu alte tipuri de aeronave cunoscute. Realizările din ultimul deceniu confirmă că specialiștii români sunt capabili să conceapă, să proiecteze și să construiască UAV-uri la nivel tehnologic și operațional comparabil cu cel obținut de marii producători internaționali care creează premisele dezvoltării unui subsector pentru industria aeronautică națională, [ㅁ]

\section{TENDINȚE VIITOARE PRIVIND VEHICULELE AERIENE FĂRĂ PILOT}

Următoarea generație de UAV va executa misiuni mai complexe, cum ar fi lupta aeriană; detectarea, recunoașterea și distrugerea țintei; lovirea / reprimarea apărării aeriene a inamicului; atac electronic; nod de rețea / releu de comunicații; livrare / livrare aeriană; război de nave anti-suprafață; război antisubmarine; ofensivă / defensivă aeriană și transport aerian.

Modificările potențiale includ crearea unui sistem de gestionare a informațiilor pentru schimbul de date între utilizatorii și furnizorii de gestionare a traficului aerian, introducerea navigației 4-D la mare altitudine și dezvoltarea unor proceduri alternative de separare pe rută. Tehnologia de autonomie care va deveni importantă pentru dezvoltarea viitoarelor UAV-uri se încadrează în următoarele categorii: 
- fuziunea senzorilor: combinarea informatiilor de la diferiți senzori pentru utilizare la bordul vectorului aerian,

- comunicațiile: gestionarea comunicării și coordonării între mai mulți agenți în prezența informațiilor incomplete și imperfecte,

- planificarea zborului (denumită și planificarea rutei): determinarea unei căi optime pentru parcurgerea traseului în timp ce îndeplinește anumite obiective și constrângeri, cum ar fi obstacolele,

- generarea traiectoriilor: determinarea unei manevre optime de control adoptată pentru a urma o cale dată sau pentru a merge dintr-o locație în alta,

- alocarea și planificarea sarcinilor: determinarea distribuției optime a sarcinilor între un grup de agenți, cu restricții de timp și echipamente,

- tactica de cooperare: formularea unei secvențe optime și distribuirea spațială a activitătilor între agenți pentru a maximiza șansele de succes în orice scenariu de misiune dat.

- Managementul inteligent al misiunilor (IMM- Intelligent Mission Management) , este deasemenea important pentru dezvoltarea viitoare a UAV-urilor.[4]]

\section{CONCLUZII}

Prezența sistemelor UAV, în spațiul aerian modern în viitorul apropiat va fi sprijinită pe toate nivelurile cum ar fi: cercetarea, fabricația, şi/sau utilizarea, specializarea datelor pe piața UAV HALE și previziuni pentru investiții globale.

Implementarea, dezvoltarea și diferențele de echipament duc implicit la diferența dintre costuri și capacități ale acestor aeronave care au deja o istorie a lor, o evoluție proprie față de alte categorii de aeronave cunoscute.

Există trei moduri distincte de integrare a sarcinilor executabile care sunt analizate de sistemele UAV. Coroborat cu alte sisteme de luptă aparținând altor categorii de aeronave: sistemele de luptă asociate sunt o resursă operațională specializată, alocată prin „amestecarea” sistemelor. În prezent, sunt trei factori determinanţi în acest amestec pentru a motiva utilizarea UAV-urilor:

- avansul tehnologic care asigură un nivel de operare semnificativ, 
- starea în evoluție a lumii aflată în continuă schimbare,

- sistemele de tip UAV care permit noile beneficii și capacități operaționale.

Astăzi, UAS joacă un rol din ce în ce mai mare în multe misiuni publice, precum supravegherea frontierei, sondaje asupra faunei sălbatice, instruire militară, monitorizare a vremii și aplicarea legii . Drept urmare, sistemele de avioane fără pilot (UAS) au necesitat mai multe explorări. [4]]

Proiectele UAS sunt produsul creației tehnice în măsura în care sunt procese creative ca instrumente ale gândirii convergente, axate pe rezolvarea unor probleme sau obiective. Proiectele care implică inițierea de soluții inovatoare oferă noi concepte multidisciplinare și transdisciplinare care necesită o logistică umană semnificativă și resurse consumatoare de timp.[ㅁ]

\section{REFERINȚE}

[1] Prisacariu V., Cîrciu I., Luchian A., Unmanned aircraft vehicle (UAV) in the Romanian airspace an overview, Journal of Defense Resources Management (JoDRM) 5 (1)/2014, p123-128.

[2] Public Law (PL) 104-113, National Technology Transfer and Advancement Act of 1995, disponibil la https://www.govinfo.gov/content/pkg/PLAW-104publ113/pdf/PLAW104publ113.pdf (data accesării 10.02.2020)

[]ㅡ Unmanned Systems Roadmap 2007-2032 - link https://www.globalsecurity.org/intell/library/reports/2007/dod-unmanned-systemsroadmap_2007-2032.pdf, Chapter 3. Interoperability and Standards - pag. 13-15 (data accesării 12.02.2020)

[4] Suraj G. Gupta, Mangesh M. Ghonge, Dr. P. M. Jawandhiya, Review of Unmanned Aircraft System (UAS), International Journal of Advanced Research in Computer Engineering \& Technology (IJARCET) pag.1646-1658

[므 Prisacariu V., Cioacă C.,Boșcoianu M., Consideration regarding of the aircraft innovative concept, Review of the Air Force Academy, vol.38, 3/2018, ISSN 1842-9238; e-ISSN 2069-4733, DOI: 10.19062/1842-9238.2018.16.3.1. 
[] ] Office of Management and Budget (OMB) Circular A-119, Federal Participation in the Development and Use of Voluntary Consensus Standards and in Conformity Assessment Activities, 1998, disponibil la https://www.whitehouse.gov/wpcontent/uploads/2017/11/Circular-119-1.pdf, (data accesării 12.02.2020)

[7] DoD 4120.24-M, Defense Standardization Program Policies and Procedures, disponibil la https://edsis.eda.europa.eu/Files ¿US\%20DOD\%20DSP\%20Procedure\%20412024m\%20.pdf, (data accesării 12.02.2020)

[]]Reglementare Aeronautică Civilă Română RACR-AZAC "Admisibilitatea la zbor a unor categorii de aeronave civile", ediţia 01/2007, disponibil la http://www.caa.ro/media/docs/C.2.2.b_RACR-AZAC Ed_1.pdf, (data accesării 09.02.2020)

[9] Aeronave civile fara pilot la bord - conditii privind comercializarea aeronavelor precum și planificarea si desfasurarea activitatilor de zbor, disponibil la http://www.caa.ro/page/rpasuavdrone (data accesării 10.02.2020) 